\author{
Marquette University \\ e-Publications@Marquette
}

College of Communication Faculty Research

and Publications

Communication, College of

2014

\title{
Humor Works in Funny Ways: Examining Satirical Tone as a Key Determinant in Political Humor Message Processing
}

\author{
Heather L. LaMarre \\ Temple University \\ Kristen D. Landreville \\ University of Wyoming \\ Dannagal Young \\ University of Delaware \\ Nathan Gilkerson \\ Marquette University, nathan.gilkerson@marquette.edu
}

Follow this and additional works at: https://epublications.marquette.edu/comm_fac

Part of the Communication Commons

\section{Recommended Citation}

LaMarre, Heather L.; Landreville, Kristen D.; Young, Dannagal; and Gilkerson, Nathan, "Humor Works in Funny Ways: Examining Satirical Tone as a Key Determinant in Political Humor Message Processing" (2014). College of Communication Faculty Research and Publications. 151.

https://epublications.marquette.edu/comm_fac/151 
Marquette University

e-Publications@Marquette

\section{Communication Faculty Research and Publications/College of Communication}

This paper is NOT THE PUBLISHED VERSION; but the author's final, peer-reviewed manuscript. The published version may be accessed by following the link in the citation below.

Mass Communication and Society, Vol. 17, No. 3 (2014): 400-423. DOI. This article is (C) Taylor \& Francis (Routledge) and permission has been granted for this version to appear in e-Publications@Marquette. Taylor \& Francis (Routledge) does not grant permission for this article to be further copied/distributed or hosted elsewhere without the express permission from Taylor \& Francis (Routledge).

\section{Humor Works in Funny Ways: Examining Satirical Tone as a Key Determinant in Political Humor Message Processing}

Heather L. LaMarre

School of Media and Communication, Temple University

Kristen D. Landreville

Department of Communication \& Journalism, University of Wyoming

Dannagal Young

Department of Communication, University of Delaware

Nathan Gilkerson

Diederich College of Communication, Marquette University

\section{Abstract}

This multi-experiment study builds upon extant political entertainment theory, testing whether satire type (horatian versus juvenalian) cues varying processing mechanisms (message discounting versus resource allocation), and if consequential differences to argument scrutiny levels or message persuasiveness result. Using novel stimuli (e.g., animated cartoons, study one) and real-world late-night political satire (The Daily Show and The Colbert Report, study two), results suggest that satire type was a key antecedent in political 
humor message processing. Additionally, the varying mechanisms had differential effects on political argument scrutiny levels and message persuasiveness.

\section{INTRODUCTION}

Throughout history, satire's social and political influence has been deemed significant to public affairs. Feinberg (1967) details such influence, describing how Plato equated satire with magic when he proposed laws against satirists and magicians. England saw the forbiddance of the publication of satire in 1599. Even in the 21st century, state-sponsored censorship and hostility toward satire continues. The 2005 worldwide protests of countries whose newspapers published political cartoons of the Islamic prophet Muhammad led to Iran threatening to start an international Holocaust cartoon competition (BBCNews.com, 2006). Indeed, Feinberg (1967) argued that the relevance of satirical texts lasts for ages because of universal values, problems, and issues that transcend any one society.

Against the backdrop of popular late-night comedy shows and political satire in today's society, political and strategic communication scholars have renewed interest in the potential socio-political influence of satire. Still, as scholars work to better understand the role of political satire in modern public opinion, theoretical approaches have remained somewhat fractured. Namely, key socio-psychological based message processing theories regarding satire's role in shaping socio-political attitudes offer competing - even contradictory propositions of how humor is cognitively processed (e.g., Young, 2008; Baumgartner, 2007; Nabi, Moyer-Guśe, \& Byrne, 2007; Baumgartner \& Morris, 2008). Holbert, Hmielowski, Jain, Lather, and Morey (2011) provided a significant contribution to the political entertainment literature, introducing the concept of satire type as a key, moderating variable in humor effects research. In their study, Holbert and colleagues demonstrated that differing types of satire have significantly different influences on individuals. Such findings offer important insights into how and when people process political messages embedded within entertainment programming, and lead us to consider issues of agency - whether it lie with the message recipient or with the message source.

\section{Satire Types}

Most conceptualizations of satire are grounded in the humanistic tradition of literary criticism (e.g., Bogel, 2001; Feinberg, 1967; Highet, 1962; Knight, 2004; Sander, 1971; Simpson, 2003). In general, satire uses laughter as a weapon to diminish or derogate a subject and evoke toward it attitudes of amusement, disdain, ridicule, or indignation (Abrams, 1999). Satire has been described as a "playfully critical distortion of the familiar" (Feinberg, 1967, p. 19) and as having a larger purpose than to simply generate laughter (Feinberg, 1967). While there are many forms of satire, two of the most popular and distinct types are horatian satire and juvenalian satire. Conceptually speaking, the two types of satire have been described as opposites in terms of their techniques: "If Horace's satire borders on comedy, Juvenal's comes close to tragedy. If Horace's satire evokes laughter, Juvenal's provokes indignation ..." (Sander, 1971, p. 254). Horatian satire, named for the first Roman satirist Horace (65-8 BC), is "to tell the truth, laughing" of social and ethical problems (Highet, 1962, p. 234). Juvenalian satire, named for a second early Roman satirist Juvenal (60-140 AD), is a more definitive, bitter approach to satire (Highet, 1962; Sander, 1971).

Unfortunately, there are no existing studies that empirically test all the dimensions on which these two forms of satire vary. Instead, the conceptual and operational definitions used in prior empirical political satire processing studies originate from English literature, offering explanatory conceptualizations of horatian and juvenalian that generally describe the dimensions on which these two types of satire vary (e.g., pessimism/optimism, tragedy/comedy, harsh/gentle) (e.g., Bogel, 2001; Feinberg, 1967; Knight, 2004; Simpson, 2003). Because satire exploits preexisting genres, all forms of satire involve mimicry (Knight, 2004). Juvenalian mimics the literary genre of tragedy, where horatian mimics the literary genre of comedy (Sander, 1971). From this viewpoint, it is 
helpful to conceptualize these two distinct forms of satire as falling at (or near) the ends of a continuum of mimicry of literary genres (Feinberg, 1967; Knight, 2004; Sander, 1971; Simpson, 2003; see also Cantor, 1999).

In doing so, the operationalization of horatian and juvenalian satire focuses on how they attempt to influence audiences (e.g., differences in sardonic technique). Prior empirical work on satire types has relied upon this distinction to conceptually define and operationalize the two forms in terms of their satirical tone and methods. For example, Holbert et al. (2011, pp. 191-192) defines horatian satire as "lighter than juvenalian satire" and more interested in producing a "wry smile in audience members." Likewise, they note that "Juvenalian satire is much more acidic in tone" (p. 192). Situating horatian and juvenalian as two forms of satire that employ different sardonic techniques, this study extends Holbert and colleagues' (2011) work to include examinations of the underlying mechanisms cued by horatian and juvenalian satire. The primary purpose is to test whether horatian and juvenalian satire cue different processing mechanisms, and if said differences result in substantive influences on agency, argument scrutiny, or subsequent political judgments.

\section{Political Satire Message Processing}

Prior empirical message effects literature offers several possible explanations, some explicit and others implicit, for how different satire types or forms potentially influence which mechanisms are cued during cognitive processing. For instance, Baumgartner and Morris (2008) pointed to Stephen Colbert's complex form of satire as causing difficulty for audiences to properly interpret his meaning. LaMarre, Landreville, and Beam (2009) proposed a bias processing mechanism, similarly stating that Colbert's sardonic techniques led individuals to process his humor in biased ways. Both studies suggested that Colbert's particular brand of satire (which has been classified as juvenalian, see Holbert et al., 2011, p. 192) affected audiences' ability and/or motivation to process the political messages. Nabi et al. (2007) approached satire processing from a different perspective, outlining a peripheral process in which individuals were cued by the humor to actively discount political satire messages as unimportant to political decision-making (see below for a detailed explanation of message discounting). Here again, Nabi and colleagues (2007) indicated that the message form (e.g., satire) cued the discounting mechanism. Alternatively, Young (2008) offered a resource allocation hypothesis in which the cognitive load required to process satirical humor reduced individual-level resources available for scrutinizing the political arguments (see below for a detailed definition of resource allocation). LaMarre and Walther (2013) extended Young's (2008) work to include an Elaboration Likelihood Model (ELM; Petty \& Cacioppo, 1986) explanation, finding that differential levels of ability influenced individual-level argument scrutiny and affected political opinion among late-night comedy viewers.

Integrating the various content, processing, and effects studies into a normative theory of political satire, Holbert (2013) addressed the link between satire types and message elements stating, "Theorists have identified some classic types of political satire (e.g., Juvenalian, Horatian, Minnepian), but a wide variety of message elements nest within each of these classifications (see Knight, 2004)" (p. 306). Additionally, classic satire literature situates the presentation of content (including which information is made salient or how the joke target is portrayed) as part of the overall sardonic technique that creates distinct satirical styles (e.g., Feinberg, 1967; Highet, 1962; Sander, 1971). Taken together and considering the conceptualization of satire types offered above, these studies generally suggest that how the satire is presented (e.g., sardonic technique, media format, salient content, etc.) consequentially affects message processing and effects (emphasis added). The current examination seeks to bridge this line of research with Holbert et al.'s (2011) first empirical examination of political satire processing antecedents (e.g., satire type). Specifically, we extend the examination of antecedents affecting satire processing and integrate prior process models by offering a dual-path conceptualization. In doing so, we suggest that satire types (horatian versus juvenalian) serve as antecedents cueing specific processing mechanisms (message discounting versus resource allocation, respectively), which in 
turn, consequentially influence agency, argument scrutiny, and political judgments (as detailed below, see Figure 1).

FIGURE 1 Political Satire Processing paths: Message Discounting versus Resource Allocation. (Color figure available online.)

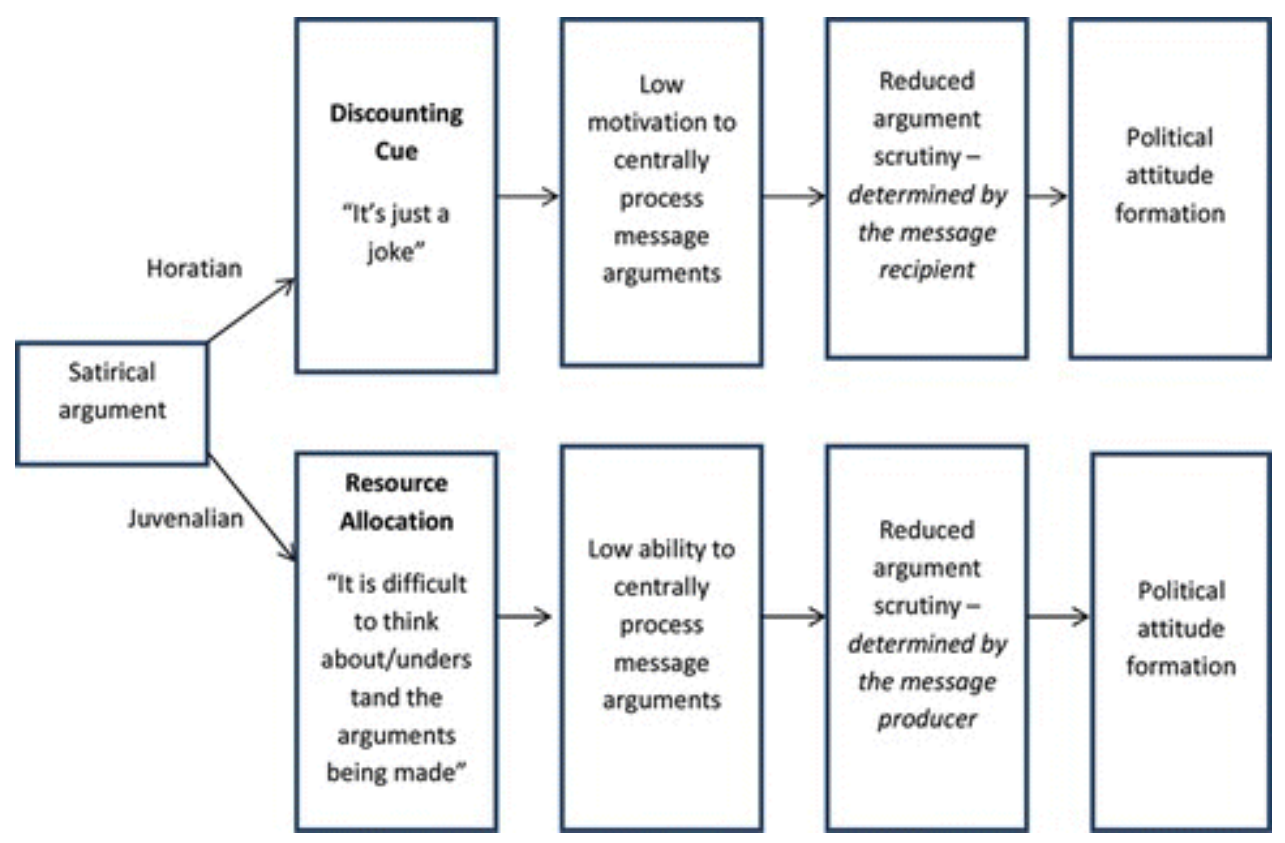

Two Paths to Satire Processing: Message Discounting and Resource Allocation

Message discounting is a process wherein individuals are cued by the humor to discount political arguments embedded in satirical humor as 'just a joke' or 'not serous', thereby reducing one's propensity to consider the arguments relevant to political judgment-making (Nabi et al., 2007). Alternatively, resource allocation is conceptualized as the proportion of cognitive activity devoted to joke interpretation as compared to the amount devoted to considering the political arguments with the satire. Young's (2008) resource allocation hypothesis suggests a process in which the message form (e.g., satire) requires individuals to divert cognitive resources to interpreting the joke (reconciling the gap between what the satirist said and what he/she actually meant), leaving relatively less resources available for thinking about the political arguments embedded in the satirical humor. Where discounting is situated as reducing one's motivation to consider the merits of the political arguments within the satire (e.g., "because it's just a joke, it isn't relevant or worth consideration"), resource allocation is situated as reducing one's ability to consider them (e.g., "I had a hard time thinking about the political arguments" or "It was difficult to understand what the jokes meant"). While these two processing mechanisms are not in direct opposition with one another, they suggest distinctly different paths for humor processing which nicely align with horatian and juvenalian satire.

Recalling that horatian satire mimics comedy with an aim of evoking laughter (Highet, 1962; Sander, 1971; Simpson, 2003), it is reasonable to suspect that this type of satire cues message discounting. Horatian satire does not convey a sense of urgency; instead it offers a humorous commentary of socio-political ills, which calls audiences to laugh at the folly of political circumstance without giving much credence to arguments (Holbert et al., 2011; Knight, 2004). Individuals who consume this form of satire are more likely to engage in message discounting, dismissing the arguments as 'not serious' or 'just a joke'. Message discounting has been operationally defined in this manner, using perceptions of message goal/importance (e.g., "The message was intended more to entertain than to persuade" and "It would be easy to dismiss this message as simply as joke") 
to measure discounting (see Nabi et al., 2007). Thus, we suggest that horatian satire is more likely to cue the discounting mechanism.

Alternatively, juvenalian satire is said to provoke indignation (Abrams, 1999; Sander, 1971), and has been shown to evoke a stronger sense of urgency (Holbert et al., 2011). Mimicking tragedy (as opposed to comedy), this form of satire is potentially more difficult to interpret, requiring audiences to close a broader gap between what the satirist says and what he/she means (Feinberg, 1967; Holbert et al., 2011; Sander, 1971). Perhaps juvenalian satire is what Young (2008) had in mind when she argued that complex forms of satire require a heavier cognitive load. Certainly, mimicking tragedy requires more of the audience (in terms of reconciling the humor) than does mimicking comedy. Because juvenalian satire likely demands relatively more cognitive activity to interpret the joke and make sense of the satire, we suspect that it cues resource allocation. Unfortunately, individuals cannot easily discern the proportion of cognitive resources devoted to understanding what the satirist meant versus scrutinizing what the satirist said, making it somewhat difficult to operationalize the mechanism. Prior empirical work has operationalized resource allocation by measuring individual-level perceptions of how difficult it was to think about the political messages within satire (e.g., "I found it difficult to think about the political points made in the video"; see Young, 2008).

Returning to conceptual differences, message discounting is a process through which one purposefully decides which (if any) political arguments contained within the humorous message merit serious consideration. Here, the individual is thought to have control over this process, suggesting that agency belongs to the receiver during humorous political message processing. In contrast, the resource allocation hypothesis puts agency in the hands of the message source. As more of the audience's cognitive resources are diverted to interpreting the satire, less are available for scrutinizing the message. This takes agency largely out of the hands of the message recipient, and suggests that satirists can maintain relatively more control over the political message by employing complex sardonic techniques. Although the mechanisms are thought to have differences in agency, they have both been associated with reduced argument scrutiny and peripheral processing (Nabi et al., 2007; Young, 2008; see also Holbert, 2013; LaMarre \& Walther, 2013). This begs the question of how agency affects the process (e.g., Do differing levels of agency lead to consequential differences in argument scrutiny reduction or persuasive outcomes?).

\section{Agency, Argument Scrutiny, and Persuasive Effects}

Because the two processing mechanisms (message discounting and resource allocation) are associated with different levels of agency, it is plausible that differences in the reduction of argument scrutiny could also occur. Dual-process persuasion theories such as the ELM (Petty \& Cacioppo, 1986) note that argument scrutiny lies on a continuum, meaning that even within peripheral processing, scrutiny levels can very. As such, the proposed differences in agency suggested by the two mechanisms could lead to different levels of argument scrutiny reduction. This difference in the amount of argument scrutiny allowed through each mechanism, in turn, would have consequential implications for the kinds of political judgments that could result. To test the dual-path processing explanation outlined above and investigate potential differences between the mechanisms, two experimental studies were conducted: one using animated political satire cartoons and the other using latenight comedy. ${ }_{-}^{1}$

\section{STUDY ONE: ANIMATED POLITICAL SATIRE}

This study uses animated political satire to examine if satire type can cue different processing mechanisms, and if such differences lead to significant differences in argument scrutiny and in subsequent attitudes on messagerelevant issues. With a growing number of popular animated series such as South Park, The Simpsons, and Family Guy, animated comedy shows offer novel avenues for satirizing social and political issues (Kondolojy, 2013). Animated characters are not bound by the same professional concerns that temper 
journalists, providing them more freedom to openly ridicule politicians and public policies when compared their news counterparts (Cantor, 1999; Darr \& Barko, 2004). Animated characters are also free from the potential scrutiny that late-night comedy hosts (e.g., Jon Stewart and Stephen Colbert) and other political comedians encounter when audiences perceive them as crossing the line (Baumgartner, 2007). Thus, the producers of animated series are free to develop complex satirical commentary, hence making online animated satire a fitting object of inquiry (Baumgartner, 2007; Cantor, 1999; Darr \& Barko, 2004). Consequently, the first examination of satire types and processing mechanisms uses animated political satire to test whether horatian satire cues message discounting while juvenalian satire cues resource allocation. More formally hypothesized as follows:

H1: The horatian satire group will experience significantly higher levels of message discounting than the juvenalian satire group.

H2: The juvenalian satire group will experience significantly higher levels of resource allocation than the horatian satire group.

Additionally, potential differences in argument scrutiny reduction and attitude change are also examined. Because there are no prior empirical studies to guide questions of agency that could subsequently affect argument scrutiny or resulting persuasion, these are offered as research questions.

RQ1: Do the horatian and juvenalian satire groups report significantly different levels of argument scrutiny?

RQ2: Does argument scrutiny negatively predict political message agreement?

\section{STUDY ONE METHOD}

Using a posttest only experimental design, participants were randomly assigned to one of three animated political satire conditions (e.g., horatian, juvenalian, and control) in which they viewed the stimulus and then answered questions about the animated satire and the political topic covered in the video (i.e., healthcare reform).

\section{Procedure and Participants}

University students were recruited from an undergraduate research pool at a large mid-western university. Participants were randomly assigned to one of the three experimental conditions (e.g., horatian satire, juvenalian satire, or control). Using email correspondence, unique links granted participants access to the study. Each participant had one week to complete the study. Also, upon exiting the survey their link expired. All participants used private computers to complete the study and were instructed to do so in a quiet environment without assistance from others. The process lasted approximately 25 minutes.

The sample $(N=115)$ was approximately $73 \%$ female. All participants were over 18 , and the average age was approximately $22(S D=1.01)$. The majority of participants $(86.9 \%)$ self-reported their race/ethnicity as Caucasian, and the mean political ideology was "somewhat liberal" $(M=3.78, S D=.189)$ on a 7-point scale ranging from "extremely liberal (1)" to "extremely conservative (7)". Overall, the average level of participants' issue interest (on the topic of the stimuli - healthcare) was "somewhat interested in the national healthcare issue" $(M=3.22, S D=.087)$ on a 5-point scale ranging from "not at all interested (1)" to "extremely interested (5)".

\section{Experimental Stimuli}

In an effort to control potential confounding variables, both treatment videos were valenced in the same direction (i.e., supporting healthcare reform). Additionally, both treatment videos similarly used original characters (novel to participants) with audio voice-overs that conveyed parallel arguments regarding the flaws within the current healthcare system. However, using real-world animation often poses an issue where technical 
differences (e.g., complexity of graphics, likability of characters) can create confounds. In an attempt to alleviate this issue, stimuli whose differences played into the operationalization of satire type (i.e., sardonic method) were selected.

The horatian video featured buoyant, super-hero animals that mimicked the comedy of animated super-hero cartoons. ${ }^{2}$ Dubbed the "The Insur-animals," the horatian satire used pun-filled stories where characters like "Denial Crocodile" and "Co-pay Cobra" mocked rising premiums, increased co-pays, and pre-existing condition denials. For instance, as the boy in video breaks his leg, "Deductibear" warns, "You better think before you sink into debt from medical bills, emergency room visits are expensive." Co-pay Cobra also warns against seeking medical care saying, "Co-pays will take a bite out of your wallet." When the boy's friend suggests x-rays, Denial Crocodile informs the boy that he can't get x-rays because his "leg was broken when we [the Insur-animals] got here." For this stimuli, three similar videos (each about 1.5 minutes in length) were edited together to equal the length of the juvenalian video (described next). All three horatian videos used the same satirical style, the sardonic technique employed was "to tell the truth, laughing" of social and ethical problems (Highet, 1962, p. 234).

Alternatively, the juvenalian video ${ }_{3}^{3}$ featured austere stick figures that conveyed grim representations of our current healthcare system, while arguing "why we need government-run, universal, socialized, call it what ever you want health care". The sardonic technique employed in the juvenalian video included harsh repudiation of our current healthcare system, with statements derogating private insurance companies for using money on "things that aren't remotely connected to caring for people's health like paying for political campaigns to fight against healthcare reform." The voice-over offered a series of critical arguments with a sense of authority often associated with juvenalian satire (Knight, 2004), while the graphics included caricatures of executives receiving big bonuses for increasing profits by denying claims. Taken together, the graphics and narration in juvenalian video were clearly intended "to provoke indignation" (Sander, 1971, p. 254; Abrams, 1999).

These stimuli nicely juxtapose the two satire types, where the horatian video "borders on comedy" and the juvenalian video "comes closer to tragedy" (Sander, 1971, p. 254). For the control condition video, a similar length "Tom and Jerry" cartoon was shown to participants before completing the identical survey. The animated "Tom and Jerry" cartoon included no messages relevant to politics or healthcare. ${ }_{-}^{4}$

\section{Measures}

\section{Discounting}

Message discounting was measured using a 4-item scale adapted from Nabi et al. (2007) $(M=2.12, S D=.355$, $\alpha=.879$ ). All items were measured on a 5-point Likert-type scale that ranged from "strongly disagree (1)" to "strongly agree (5)" and used the following items: "The author of the message was just joking," "The message was intended more to entertain than to persuade," "The author was serious about advancing his views in the message (reversed)," and "It would be easy to dismiss this message as simply as joke."

\section{Resource allocation}

Resource allocation was adapted from Young's (2008) resource allocation hypothesis. The 3-item index measures one's ability to think about or attend to the political message, based on Young's (2008) operationalization that suggests ability and attention (to the political messages) decline as more resources are allocated to reconciling the humor itself $(M=3.54, S D=.994, \alpha=.840)$. Participants were asked to agree or disagree on a 5-point scale ranging from "strongly disagree (1)" to "strongly agree (5)" with the following statements: "I found it difficult to think about the political points made by the video," "I was able to pay close attention to the political arguments put forth in the video (reversed)," and "It was easy to understand the healthcare arguments made in the video (reversed)." 


\section{Argument scrutiny}

A single item was used to measure argument scrutiny. Participants were asked to agree/disagree on a 5-point scale ranging from "strongly disagree (1)" to "strongly agree (5)" with the following statement: "I was looking for flaws in the political arguments made in the video" $(M=3.17, S D=1.25)$.

\section{Political message agreement}

To measure the level of agreement with the political message (i.e., pro healthcare reform), a two-item index was created. Participants were asked to agree or disagree on a 5-point scale ranging from "strongly disagree (1)" to "strongly agree (5)" with the following statements: "I am generally supportive of proposals for universal healthcare reform" and "The current U.S. healthcare system is broken and needs reformed"

$(M=2.31, S D=1.07, r=.67, p<.01)$.

\section{Manipulation check}

Participants who could not see or hear the video were excluded from the analyses. This resulted in a slightly smaller sample $(n=94)$. Because satire type was operationalized by sardonic technique, a good manipulation should produce significant differences in perceptions of tone. To measure perceptions of tone, participants were asked how much they agreed/disagreed on a 5-point scale ranging from "strongly disagree (1)" to "strongly agree (5)" with the following two statements: "The tone of the video was light-hearted/serious" (lighthearted $M=2.84, S D=1.10$; serious $M=2.93, S D=1.28$ ). Additionally, if the stimuli properly represented mimicry that provoked laughter (horatian) versus indignation (e.g., expressions of anger or outrage toward the joke target) (juvenalian) (Sander, 1971, p. 254) then significant differences between groups should emerge along these indicators. To check this, participants were asked how much they agreed/disagreed on the same 5-point scale with the following two statements: "The video made me laugh" $(M=2.95, S D=1.09)$ and "The video made me angry about our healthcare system" $(M=3.04, S D=1.49)$. The manipulation check results are reported below.

\section{Analyses}

Multivariate analysis of variance (MANOVA) was used to test the relationship between the satire type and the dependent variables under study; namely, discounting, resource allocation, and argument scrutiny. The fixed factor (satire condition variable) contained three groups: horatian satire, juvenalian satire, and control. Because random assignment worked (see below), covariates were not included in the model. Significant effects were further probed using pair-wise comparisons with Bonferroni's adjustment for multiple comparisons. To examine RQ2, argument scrutiny was situated as the independent variable predicting political message agreement (e.g., support for healthcare reform) in an OLS regression (controlling for demographics, political ideology, and issue interest).

\section{STUDY ONE RESULTS}

The horatian condition comprised $30 \%(n=28)$ of the sample while the juvenalian condition was $40 \%(n=37)$ and the control condition was $30 \%(n=29)$. Slight size variations between groups occurred as a result of deleting those who could not hear/see the video from the sample. No significant differences emerged between groups for race $\left(X^{2}(2)=1.55, p=.36\right)$, age $(F(2)=1.67, p=.19)$, gender $\left(X^{2}(2)=.764, p=.683\right)$, political ideology $(F(2)=.36, p=.69)$, or issue interest $(F(2)=2.64, p=.08)$, indicating successful randomization to treatment conditions.

\section{Manipulation Check Results}

Significant differences in perceptions of tone emerged between the two types of satire, as expected $(F(2$, $93)=36.85, p<.001)$, with the horatian group perceiving their video significantly more light-hearted in tone 
satirical video $(M=3.75, S E=.183, p<.001)$ than the juvenalian group $(M=2.00, S E=.123)$ and the control group $(M=3.03, S E=.145, p<.01)$. Additionally, the juvenalian group perceived their video as significantly more serious in tone $(F(2,93)=91.29, p<.001 ; M=4.22, S E=.111)$ than did the horatian group $(M=2.25, S E=.151, p<.001)$ and control group $(M=1.93, S E=.148, p<.001)$. Regarding the manipulation check for sardonic technique, significant differences emerged between the groups' responses for laughter $(F(2$, $93)=7.79, p=.001$ ). The non-political cartoon (control group) reported the highest level of laughter $(M=3.31, S E=.211)$, but only significantly differed from the juvenalian group (juvenalian $M=2.43$, $S E=.162, p<.01$; horatian $M=3.25, S E=.175, p=1.00$ ). However, the horatian group reported that the video made them laugh significantly more than the juvenalian group $(p<.01)$. Additionally, significant differences also emerged for anger $(F(2,93)=86.65, p<.001)$. The juvenalian group reported feeling significantly more angry $(M=4.27, S E=.092, p<.001)$ than the horatian group $(M=3.14, S E=.228, p<.001)$ or the control group $(M=1.38, S E=.160, p<.001)$. Overall, it appears that the manipulation was successful.

\section{Main Effects}

There was a significant main effect for satire type on discounting, $F(2,93)=88.73, p<.001$. Closer examination of estimated marginal means revealed that, consistent with $\mathrm{H} 1$, participants in the horatian condition $(M=3.97, S E=.129)$ discounted the message significantly more than those in the juvenalian condition $(M=3.52, S E=.112, p<.05)$ and those in control condition $(M=1.72, S E=.127, p<.001)$. Additionally, there was a significant difference for discounting between the juvenalian group and the control group $(p<.001)$. A significant main effect was also found for satire type on resource allocation $(F(2,93)=17.02, p<.001)$. Consistent with $\mathrm{H} 2$, participants in the juvenalian group reported significantly higher resource allocation $(M=4.07, S E=.141)$ than participants in the horatian group $(M=3.54, S E=.163, p=.05)$ or the control group $(M=2.82, S E=.160, p<.001)$. Participants in the horatian group also experienced significantly higher levels of resource allocation than those in the control group $(p<.01)$. The significant differences between each of the test groups and the control on both mechanism measures makes sense, given the fact that the control stimulus did not offer any arguments. Since the discounting and resource allocation measures pertain to message argumentation and persuasion, it is logical that those in the Tom and Jerry (control) would score lower on both of these processing measures.

In response to RQ1, a significant main effect was found for satire type on argument scrutiny $(F(2$, $93)=5.57, p<.01$ ), but post hoc comparisons showed it was only significant between the control group $(M=3.62, S E=.223)$ and the juvenalian group $(M=2.67, S E=.197, p<.05)$, with argument scrutiny significantly lower in the juvenalian condition than in the control. There were no significant differences in overall scrutiny levels between the horatian $(M=3.37, S E=.231)$ and control groups $(p=1.00)$. The difference in scrutiny levels between the horatian and juvenalian approached significance $(p=.07)$ with the horatian group scrutinizing the political messages relatively more than the juvenalian group. Finally, the results for RQ2 indicate that increased levels of argument scrutiny significantly predicted lower levels of message agreement, controlling for demographics, political ideology, and issue interest (the regression results are interpreted as the more one looked for flaws, the less support they reported for healthcare reform; $b=-.223, S E=.089, p<.05$ ).

\section{STUDY ONE DISCUSSION}

Study One offers a good 'first look' at examining whether satirical tone influenced the underlying processing mechanisms at work. The horatian message discounting $(\mathrm{H} 1)$ and juvenalian resource allocation $(\mathrm{H} 2)$ hypotheses were supported. Although differences between satire groups in argument scrutiny levels didn't reach significance (RQ1), the results revealed that both satire groups scrutinized less than the control group with the juvenalian group reporting the least amount of argument scrutiny. 


\section{Limitations and Next Steps}

As with any study, these results must be tempered by the limitations of the study. For example, the lack of robust findings could be attributed to the small sample size in each condition. In addition, the juvenalian satire stimulus was so grim in its approach that it could have been construed as an animated set of rhetorical arguments (opposed to a satirical argument). Although the manipulation check worked and this form of satire uses a style that "comes closer to tragedy" (Sander, 1971, p. 254), this potential confound makes it difficult to fairly conclude that the juvenalian satire led to increased resource allocation. Additionally, the first study was limited in scope and stopped short of considering important individual differences known to affect message processing (e.g., enjoyment, see Landreville \& LaMarre, 2013). Also, these hypotheses should be tested beyond the limited context of online, animated viewing using a more ecologically valid context of study. The second study attempts to remedy some of these limitations, replicating and extending the first study as follows.

\section{STUDY TWO: LATE-NIGHT POLITICAL SATIRE}

To be consistent with the stimuli originally used as the basis of our key theoretical propositions (e.g., Nabi et al., 2007; Young, 2008) and to maximize ecological validity of the stimuli (e.g., by using a known political satirist to ensure operational validity), The Daily Show (TDS) and The Colbert Report (TCR) were chosen as suitable stimuli with which to replicate Study One. As of September 2013, TDS attracted just more than 2 million viewers, which was a 21\% increase from September 2012 (Faughnder, 2013). TCR attracted 1.72 million viewers in the same time period (Kondolojy, 2013). Both shows regularly attract the coveted young demographic of 18 to 49 year olds (Kondolojy, 2013). Additionally, both shows have won Emmy Awards and Peabody Awards (ColbertNation.com, 2013; TheDailyShow.com, 2013).

From a theoretical standpoint, prior research has argued (either implicitly or explicitly) that TCR leans juvenalian in its satirical approach (e.g., Day, 2011; Holbert et al., 2011; Jones, 2010; LaMarre, 2013), whereas much of TDS has been conceptualized as utilizing a horatian approach (e.g., Baym, 2005; Jones, Baym, \& Day, 2012). However, it is important to recognize the diversity of the shows' various comedic segments and avoid categorizing entire shows into either juvenalian satire or horatian satire. As such, the operationalization of TCR as juvenalian satire and of TDS as horatian satire was limited to single segments (one per show) that similarly satirized reactions to the U.S. Supreme Court decision to uphold "Obamacare"; but, did so using different sardonic techniques broadly defined as horatian (TDS) and juvenalian (TCR) in prior research (e.g., Baym, 2005; Day, 2011; Holbert et al., 2011; Jones et al., 2012). Utilizing the same theoretical framework, Study Two seeks to replicate Study One within the context of late-night political satire. Hypothesized as:

H1: The horatian satire group (viewers of TDS) will experience significantly higher levels of message discounting than the juvenalian satire group.

$\mathrm{H}$ 2: The juvenalian satire group (viewers of $T C R$ ) will experience significantly higher levels of resource allocation than the horatian satire group.

Because the first study showed some differences in argument scrutiny levels where the horatian group tended to scrutinize the political message more than the juvenalian group, a prediction for argument scrutiny is also offered:

H3: The horatian satire group (viewers of TDS) will report significantly higher levels of argument scrutiny than the juvenalian satire group.

The first study also found that individual-level argument scrutiny negatively predicted message agreement, interpreted as increased scrutiny leading to less persuasion. However, the study stopped short of examining whether a significant main effect for satire type on political message agreement (e.g., a persuasion effect) 
occurred. Here we extend Study One to also investigate whether the satire types result in differential persuasive effects. These are formally offered as follows:

H4: Individual-level argument scrutiny negatively predicts political message agreement.

RQ1: Do the horatian satire and juvenalian satire groups significantly differ in their levels of political message agreement?

\section{STUDY TWO METHOD}

A post-test only experiment $(N=168)$ embedded in an online survey was used to test the hypotheses and explore the research questions herein. Although the experimental design and procedures closely followed Study One, a larger sample size, additional measures, and improved manipulation checks (described below) were added to improve reliability and validity. As with study one, participants were randomly assigned to one of three conditions (horatian satire, juvenalian satire, or control group) where they viewed a short late-night comedy clip and subsequently answered questions regarding their message processing, attitudes, and opinions of the stimulus. To remain consistent with the political topic used in study one, the second study also used stimuli covering the U.S. healthcare issue.

\section{Participants and Recruitment}

Participants were recruited through a university research pool that invites students and non-students from across the nation to participate in research in exchange for nominal forms of compensation. Emails with randomized condition links gave participants access the study. All participants in the sample $(N=168)$ were over 18. The sample was $62.5 \%$ female and $78.6 \%$ white with a mean age of 24 (SD $=5.72$ ), an average household income between $\$ 25,000$ - $\$ 49,999$, and a mean level of education reported as "some college." The mean political ideology was "somewhat liberal" (on a 7-point scale ranging from "extremely liberal (1)" to "extremely conservative (7)." Participants' average issue interest was "somewhat interested" $(M=2.56, S D=1.04)$ on a 5point scale ranging from "not at all (1)" to "extremely (5)" interested in the national healthcare issue.

\section{Experimental Stimuli}

All three videos originally aired on June 28,2012 , and both treatment videos (TDS for horatian satire group and TCR for juvenalian satire group) covered the U.S. Supreme Court ruling of the affordable healthcare act. The control group watched a non-political clip from The Tonight Show with Jay Leno. Using three late-night comedy segments that aired on the same day provided an excellent way to replicate real world, late-night comedy viewing options audiences had immediately following the U.S. Supreme Court ruling.

\section{Horatian late-night comedy}

The Daily Show video featured Jon Stewart covering the U.S. Supreme Court ruling on the Affordable Care Act using horatian satire. While the tone was relatively buoyant, the political messages were clearly poking fun at the political process, the presidential candidates, and reactions to the highest court's decision. Stewart joked about the bill, calling it a "sneak a tax", and lauded the U.S. Supreme Court for being able to "tell the truth" and call it a tax. Although Stewart seemed to ridicule the President for his political approach, he also mocked his opponent, clearly showing that GOP presidential candidate, Mitt Romney, seemed to agree with the tenants of "Obamacare" (3 min. $36 \mathrm{sec}$.). ${ }^{5}$ Stewart was using a horatian style, mimicking comedy and attempting to "tell the truth laughing" (Sander, 1971, p. 254).

Juvenalian late-night comedy

The Colbert Report video, originally airing on the same day, covered the same U.S. Supreme Court decision in a relatively more juvenalian manner. Colbert similarly focused on the individual mandate, harshly criticizing the 
"disastrous government overreach." Colbert similarly compared "Obamacare" with "Romneycare", but in a much different manner. As opposed to Stewarts' mocking of their similarities, Colbert jeered the Court's decision, the President, and the political process ( $3 \mathrm{~min} .20 \mathrm{sec}$.). ${ }_{-}^{6}$ In doing so, Colbert parodied the indignation a conservative political talk show host might have over the Supreme Court ruling. Colbert's juvenalian satire communicated a sense of tragedy (Knight, 2004; Sander, 1971).

\section{Control late-night comedy}

For the control condition video, a segment from The Tonight Show was shown to participants before completing the survey. The control video was edited to a similar length ( $3 \mathrm{~min}$. and $29 \mathrm{sec}$.), ${ }_{-}^{7}$ featured a green screen comedy bit, and did not contain any references to the issue or politics in general.

\section{Measures}

The dependent variable measures for message discounting $(M=3.00, S D=.672, \alpha=.561)$, resource allocation $(M=2.95, S D=.977, \alpha=.791)$, and argument scrutiny $(M=2.75, S D=1.14)$ remained the same as described in Study One (see method section for details).

\section{Political message agreement}

The two separate items measured agreement levels for different aspects of the satirical arguments, asking participants to agree or disagree on a 5-point scale ranging from "strongly disagree (1)" to "strongly agree (5)" with the following statements: "I agree with the U.S. Supreme Court decision to uphold Obamacare" $(M=3.70, S D=.920)$ and "I generally support Obamacare" $(M=3.17, S D=.992)$. The correlation between the two items was non-significant $(r=.132, p=.34)$. They were used as two separate measures of message persuasion.

\section{Manipulation check}

As with the first study, a manipulation check was conducted to determine whether the stimuli properly represented mimicry that provoked laughter (horatian) versus indignation (juvenalian) (Sander, 1971). Participants were asked how much they agreed/disagreed on a 5-point scale ranging from "strongly disagree (1)" to "strongly agree (5)" with the following four statements: "The found myself laughing while watching the video" $(M=3.55, S D=1.01)$ and "I felt angry about Obamacare while watching the video" $(M=2.76, S D=1.13)$. To strengthen the manipulation check, perceptions of tone were also compared using a three-item index for perceived tone $(M=2.79, S D=.888, \alpha=.606)$. Participants indicated how much they agreed/disagreed (on a 5point scale ranging from "strongly disagree [1]" to "strongly agree [5]") with three separate statements. The statements were: "The tone of the political humor in the clip I watched was: (1) "critical", (2) "harsh", and (3) "light-hearted (reverse coded)". The manipulation checks were successful; specific results are reported below.

\section{Analyses}

Multivariate analysis of variance (MANOVA) was used to test the relationship between satire type and the dependent variables ( $\mathrm{H} 1-\mathrm{H} 3)$; namely, discounting, resource allocation, and argument scrutiny. The fixed factor (condition) contained three groups: horatian satire, juvenalian satire, and control. Because random assignment was successful (see below), covariates were not included in the models. Significant effects were further probed using pair-wise comparisons with Bonferroni's adjustment for multiple comparisons. To test $\mathrm{H} 4$, argument scrutiny was situated as the independent variable predicting political message agreement in two separate OLS regressions (controlling for demographics, political ideology, and issue interest). To further probe the relationship between experimental condition and persuasion (RQ1), a one-way ANOVA was also conducted with condition variable as the fixed factor and the two message agreement measures as dependent variables. 


\section{STUDY TWO RESULTS}

As previously mentioned, those not able to hear and see the video were excluded from the analysis. This process caused slight deviations across group sizes with $36.9 \%$ of the sample in horatian satire group, $41.1 \%$ in the juvenalian satire group, and the remaining $22 \%$ in the control group. The control group was smaller because several participants had a difficult time getting the control video to play. However, no significant differences emerged between groups for race $\left(X^{2}(2)=.431, p=.806\right)$, age $(F(2,167)=.538, p=.699)$, gender $\left(X^{2}(2)=3.05, p=.217\right)$, income $\left(X^{2}(8)=.450, p=.801\right)$, political ideology $(F(2,167)=1.99, p=.140)$, or issue interest $(F(2,167)=.747, p=.475)$, indicating that randomization was successful.

\section{Manipulation Check Results}

Regarding the manipulation check, significant differences emerged between the groups' responses for laughter $(F(2,167)=5.45, p<.05)$ with the horatian group $(M=3.74, S E=.119)$ laughing significantly more than the juvenalian group $(M=3.26, S E=.125, p<.05)$, but not significantly more than the control group $(M=3.81, S E=.158, p=1.00)$. The control group reported that the video made them laugh significantly more than the juvenalian group $(p<.05)$. Additionally, significant differences also emerged for anger $(F(2$, $167)=10.81, p<.001)$. The juvenalian group reported feeling significantly more angry $(M=3.13, S E=.125, p<.05)$ than the horatian group $(M=2.65, S E=.133)$ or the control group $(M=2.22, S E=.155, p<.001)$, but there was no significant difference between the horatian and control groups $(p=.123)$ in terms of anger. Also, using the three-item index described above, participants in the horatian group rated their satirical video as significantly less critical, less harsh, and more light-hearted in perceived tone $(M=2.43, S E=.116)$ than did those in the juvenalian group $(M=3.49, S E=.104)$, indicating that the juvenalian and horatian groups held significantly different perceptions of tone, $F(2,167)=150.15, p<.001$, in a manner consistent with our underlying propositions.

\section{Main Effects}

There was a significant main effect for satire type on discounting, $F(2,167)=13.44, p<.001$ in a direction consistent with $\mathrm{H} 1$. Closer examination of estimated marginal means revealed that participants in the horatian group $(M=3.03, S E=.084)$ discounted the message significantly more than those in the juvenalian group $(M=2.73 S E=.079, p<.05)$, but significantly less than those in the control group $(M=3.43, S E=.111, p<.05)$. Additionally, there was a significant difference for discounting between the juvenalian group and the control group $(p<.001$ ). Although The Tonight Show viewers (control group) discounted more than The Daily Show viewers (horatian group), it seems logical that non-political comedy would be judged as intending more to entertain than persuade. Yet, this can be interpreted as partial disconfirmation of $\mathrm{H} 1$.

A significant main effect was found for satire type on resource allocation $(F(2,167)=53.12, p<.001)$. Consistent with $\mathrm{H} 2$, participants in the juvenalian group reported significantly greater resource allocation $(M=3.64, S E=.092)$ than participants in the horatian group $(M=2.28, S E=.097, p<.001)$ and the control group $(M=2.75, S E=.128, p<.001)$. The horatian group also experienced significantly different levels of resource allocation from those in the control group $(p<.05)$. The significant differences between each of the test groups and the control on both mechanism measures makes sense, given the fact that the control stimulus did not offer any arguments.

A significant main effect was also found for satire type on argument scrutiny $(F(2,167)=24.81, p<.001)$, in a manner consistent with $\mathrm{H} 3$, where the horatian group $(M=3.16, S E=.113)$ scrutinized the message significantly more than the juvenalian group $(M=2.10, S E=.098, p<.001)$ and the control group $(M=2.39, S E=.161, p<.001)$. There were no significant differences in overall scrutiny levels between the juvenalian and control groups $(p=.332)$. Additionally, increased levels of argument scrutiny significantly predicted lower levels of message agreement for agreeing with the U.S. Supreme Court decision to uphold 
Obamacare (regression results are interpreted as the more one looked for flaws, the less they agreed with the U.S. Supreme Court decision, $b=-.205, S E=.074, p<.01)$. However, scrutiny level did not significantly predict one's overall support for Obamacare $(b=-.015, S E=.082, p=.855)$. The ANOVA examining differences between groups for message agreement did reveal a significant main effect for general support of Obamacare $(F(2$, $167)=3.09, p<.05)$. The horatian group reported significantly higher levels of support $(M=3.40, S E=.949)$ than did the juvenalian $(M=2.99, S E=.955, p<.05)$ and control groups $(M=3.06, S E=1.18, p<.05)$. No significant difference emerged between the juvenalian and control groups $(p=1.00)$. However, there was no main effect for agreement with the U.S. Supreme Court Decision $(F(2,167)=1.82, p=.164)$. Prior research has linked reduced argument scrutiny with message persuasiveness (e.g., Nabi et al. 2007). As such, one might have expected that the group with the lowest argument scrutiny levels (i.e., juvenalian) would demonstrate relatively more political message agreement. Possible explanations for why this did not occur are addressed in the discussion.

\section{STUDY TWO DISCUSSION}

These findings successfully replicated the first study, providing additional support for the proposition that satirical tone is related to the mechanism responsible for argument scrutiny reduction: message discounting in the face of horatian satire and resource allocation in the face of juvenalian (H1-H2). Message scrutiny was significantly lower among the juvenalian satire group, which provides some evidence that varying mechanisms (e.g., message discounting versus resource allocation) consequentially affect how much one thinks about the political arguments. Future studies should unpack these relationships, testing for differences in other cognitive activities (e.g., counter-arguing, elaboration) that result from varying processing mechanisms.

On the individual-level, the less one looked for flaws in the political arguments the more they agreed with the Supreme Court ruling; yet this didn't translate into a significant difference between groups. Instead, on the group-level, horatian satire viewers were significantly more supportive of the healthcare law than the juvenalian and control groups. Perhaps because the satire was aimed at the court's ruling, individual-level scrutiny was limited to the satirical arguments offered (as opposed to more general scrutiny of the healthcare law). While individual-level scrutiny appears to have been tied to the specific satirical topic (i.e., the Supreme Court ruling), satire type influenced general support for Obamacare. Horatian satire viewers discounted more, but thought more about the flaws in the arguments compared to the juvenalian viewers. However, the horatian satire resulted in more generalized political message agreement, which is curious. Clearly, something more complex was occurring with regard to attitude formation. Perhaps, individual difference variables known to influence processing (e.g., enjoyment, engagement, etc.) moderated the process (e.g., Landreville \& LaMarre, 2013). The manipulation check demonstrating that the two types of satire invoke differential levels of laughter/indignation, also suggests that emotion or affect might play a key role.

\section{Limitations}

As political entertainment scholars have repeatedly argued, the use of actual video stimuli available for public consumption and addressing relevant political topics closely imitates the actual experience of receiving and processing a persuasive viral video and increases external validity (Young, 2008). Exposing participants to "real world" video stimuli and allowing subjects to process the messages online within their own computer environment more closely recreates the actual persuasive process. Thus, although experimental control (or lack thereof) is an obvious limitation of the study, we feel that the benefits in terms of external validity far outweigh the limitations and boundaries set forth by the methodology. Still, it should be acknowledged that political comedians often employ multiple forms of satire and parody to entertain and inform audiences (Holbert et al., 2011; Jones et al., 2012). As such, it should not be assumed that sources represent particular forms of satire unto themselves. Instead, any one slice of political satire is limited to the comedic devices and satirical tone 
used within and, as such, these findings demonstrate the importance of stimuli selection. Because different forms of satire can influence which underlying processing mechanisms are at play, it is crucial that future research carefully consider their stimuli and how such will subsequently affect their results.

\section{CONCLUSION}

Overall, this study synthesizes the political humor processing literature, conceptualizes prior theoretical frameworks in terms of their underlying mechanisms, and offers a dual-path processing framework wherein satire type (horatian versus juvenalian) is thought to cue processing mechanisms (message discounting versus resource allocation). Additionally, this study offers linkages between humor processing and agency, demonstrating that different satirical approaches can change the level of audience agency in the persuasion process. Both studies suggest that horatian satire leaves agency in the hands of the message recipient while juvenalian satire places most of the agency in the hands of the message producers. The fact that argument scrutiny was lower in the juvenalian condition - in the face of high cognitive resource allocation - suggests that biting, harsh juvenalian satire has the potential to be extremely powerful, since the audience appears to be robbed of its ability to scrutinize the underlying arguments presented. However, consistent with past research (Nabi et al, 2007) the relationship between argument scrutiny and message persuasiveness remains unclear. Both studies revealed an inverse relationship between individual-level argument scrutiny and political message persuasiveness. Still, this did not consistently translate into meaningful between-group differences along persuasive outcome variables. Put simply, something else must be going on here. Perhaps Colbert's specific brand of satire might be too difficult for audiences to reconcile (see Baumgartner \& Morris, 2008; LaMarre et al., 2009); creating biased processing effects that muddled the results.

Yet, by adding these findings to our growing body of knowledge, we begin to create more nuanced understandings of how political satire is processed, as well as what differential effects might ensue. Considering the world of sketch comedy (e.g., Saturday Night Live), comedic monologues (e.g., Bill Maher), cable punditry (e.g., The O'Reilly Factor), and political cartoon series (e.g., Family Guy, South Park), we can easily observe how political humor is infiltrating media. If, as found herein, certain forms of satire reduce the public's motivation or ability to think about the issues, assess the strength of relevant arguments, and attend to the political issues being presented, then we are entering a world where opinion, sarcasm, innuendo, parody, and satire may have more influence on our democracy than facts and relevant truths. This is where humor can become serious business.

\section{Additional information}

\section{Notes on contributors}

\section{Heather L. LaMarre}

Heather LaMarre (Ph.D., The Ohio State University, 2009) is an Assistant Professor in the School of Media and Communication at Temple University. Her research interests include political communication, public opinion, and the psychology of strategic policy narratives.

\section{Kristen D. Landreville}

Kristen D. Landreville (Ph.D., The Ohio State University, 2010) is an Assistant Professor in the Department of Communication \& Journalism at the University of Wyoming. Her research interests include political communication, entertainment media, public opinion, and new media. 


\section{Dannagal Young}

Dannagal Young (Ph.D., University of Pennsylvania, 2007) is an Assistant Professor in the Department of Communication at the University of Delaware. Her research interests include political media effects, public opinion, political satire and the psychology of political humor.

\section{Nathan Gilkerson}

Nathan Gilkerson (Ph.D., University of Minnesota, 2012) is an Assistant Professor in the Diederich College of Communication at Marquette University. His research interests include strategic communication, public relations, and political humor.

\section{Notes}

${ }^{1}$ The data were gathered under strict human subjects protocols in accordance with University of Minnesota, Internal Review Board, 2010-3-9.

${ }^{2}$ See http://www.youtube.com/watch?v=s-Cn2PZUnda for an example of the horatian video (3 videos edited to approximately 5 minutes).

${ }^{3} \mathrm{An}$ example of the juvenalian video can be found at http://www.youtube.com/watch?v=Jng4TnKay6A (approximately 5 minutes).

${ }^{4}$ The control video is available at http://www.youtube.com/watch?v=nLvgl RuGMI (approximately 4.5 minutes). ${ }^{5}$ See http://www.thedailyshow.com/watch/thu-june-28-2012/roberts--rules-of-order for an unedited copy of the horatian stimulus.

${ }^{6}$ See http://www.colbertnation.com/the-colbert-report-videos/416048/june-28-2012/obamacare---the-broccoliargument for an unedited copy of the juvenalian stimulus.

${ }^{7}$ http://www.metacafe.com/watch/hl60090017/the tonight show with jay leno iconic green screen part 1 season 20/) for an unedited copy of the control stimulus.

\section{REFERENCES}

1. Abrams, M. H. (1999). A glossary of literary terms (), 7th ed. Fort Worth, TX: Harcourt Brace.

2. Baumgartner, J. C. (2007). Humor on the next frontier: Youth, online political humor, and the JibJab effect. Social Science Computer Review, 25, 319 - 338. doi: 10.1177/0894439306295395

3. Baumgartner, J. C., \& Morris, J. S. (2008). One nation, under Stephen? The effects of The Colbert Report on American youth. Journal of Broadcasting \& Electronic Media, 52, 622 - 643. doi: 10.1080/08838150802437487

4. Baym, G. (2005). The Daily Show: Discursive integration and the reinvention of political journalism. Political Communication, 22, 259 - 276. doi: 10.1080/10584600591006492

5. BBCNews.com. (2006). Iran paper's Holocaust cartoons. Retrieved from http://news.bbc.co.uk/2/hi/middle east/4709380.stm

6. Bogel, F. V. (2001). The difference satire makes: Rhetoric and reading from Jonston to Byron. Ithaca, NY: Cornell University Press.

7. Cantor, P. A. (1999). The Simpsons: Atomistic politics and the nuclear family. Political Theory, 27, $734-749$. 
8. ColbertNation.com. (2013). About the show. Colbert Nation. Comedy Central. Retrieved from http://www.colbertnation.com/about

9. Darr, C., \& Barko, J. (2004). Under the radar and over the top: Independently-produced political videos in the 2004 presidential election. Washington, DC: Institute for Politics, Democracy \& the Internet.

10. Day, A. (2011). Satire and dissent: Interventions in contemporary political debate. Bloomington, IN: Indiana University Press.

11. Faughnder, R. (2013, Sept. 4). Jon Stewart returns to 'Daily Show' with ratings boost. Los Angeles Times. Retrieved from http://www.latimes.com/entertainment/envelope/cotown/la-et-ct-jon-stewart-dailyshow-ratings-20130904,0,1130768.story

12. Feinberg, L. (1967). Introduction to satire. Ames, IA: The lowa State University Press.

13. Highet, G. (1962). The anatomy of satire. Princeton, NJ: Princeton University Press.

14. Holbert, R. L. (2013). D eveloping a normative approach to political satire: An empirical perspective. International Journal of Communication, 7, 305 - 323. doi: 1932-8036/20130005

15. Holbert, R. L., Hmielowski, J., Jain, P., Lather, J., \& Morey, A. (2011). Adding nuance to the study of political humor effects: Experimental research on juvenalian satire versus horatian satire. American Behavioral Scientist, 55, 187 - 211. doi: 10.1177/0002764210392156

16. Jones, J. P. (2010). Entertaining politics: Satiric television and political engagement () , 2nd ed. Lanham, MD: Rowman \& Littlefield.

17. Jones, J. P., Baym, G., \& Day, A. (2012). Mr. Stewart and Mr. Colbert go to Washington: Television satirists outside the box. Social Research, 79, 3360.

18. Knight, C. A. (2004). The literature of satire. Cambridge, UK: Cambridge University Press.

19. Kondolojy, A. (2013, Sept. 26). Wednesday cable ratings: 'South Park' wins night + 'The Challenge: Rivals II', 'Key \& Peele', 'The Daily Show', 'The Colbert Report' \& more. TV by the Numbers.Zap2it.com. Retrieved from http://tvbythenumbers.zap2it.com/2013/09/26/wednesday-cable-ratings-south-park-wins-nightthe-challenge-rivals-ii-key-peele-the-daily-show-the-colbert-report-more/204972/

20. LaMarre, H. L. (2013). When parody and reality collide: Examining the effects of Colbert's Super PAC satire on issue knowledge and policy engagement across media formats. International Journal of Communication, 7, 394 - 413. doi: 19328036/20130005

21. LaMarre, H., Landreville, K. D., \& Beam, M. A. (2009). The irony of satire: Political ideology and the motivation to see what you want to see in The Colbert Report. The International Journal of Press/Politics, 14, 212 - 231. doi: 10.1177/1940161208330904

22. LaMarre, H. L., \& Walther, W. (2013). Ability matters: Testing the differential effects of political news and late-night political comedy on cognitive responses and the role of ability in micro-level opinion formation. International Journal of Public Opinion Research, 25, 303 - 322. doi: 10.1093/ijpor/edt008

23. Landreville, K. D., \& LaMarre, H. L. (2013). Examining the intertextuality of fictional political comedy and realworld political news. Media Psychology, 16, 347 - 369. doi: 10.1080/15213269.2013.796585 
24. Nabi, R. L., Moyer-Gusé, E., \& Byrne, S. (2007). All joking aside: A serious investigation into the persuasive effect of funny social issue messages. Communication Monographs, 74, $29-54$. doi: 10.1080/03637750701196896

25. Petty, R. E., \& Cacioppo, J. T. (1986). The elaboration-likelihood model of persuasion. In L. Berkowitz (Ed.), Advances in experimental social psychology (Vol. 19, pp. 123 - 205). San Diego, CA: Academic Press.

26. Sander, C. (1971). The scope of satire. Glenview, IL: Scott, Foresman, \& Company.

27. Simpson, P. (2003). On the discourse of satire: Toward a stylistic model of satirical humor. Amsterdam, The Netherlands: John Benjamins.

28. Young, D. G. (2008). The privileged role of the late-night joke: Exploring humor's role in disrupting argument scrutiny. Media Psychology, 11, 119 - 142. doi: 10.1080/15213260701837073 